\title{
An Experiment with Public-Oriented Knowledge Transfer: A Video on Quebec's Bill 10
}

\section{Expérience de transfert de connaissances axé sur le public : une vidéo sur le projet de loi 10 au Québec}

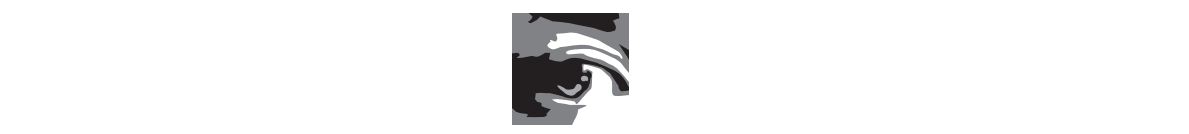

JEAN-CHRISTOPHE BÉLISLE PIPON, BSC, MA

Programmes de bioéthique, Département de médecine sociale et préventive, École de santé publique Institut de recherche en santé publique de l'Université de Montréal (IRSPUM)

Montréal, QC

MARIE-ÈVE LEMOINE, BSC, PT, MA

Programmes de bioéthique, Département de médecine sociale et préventive, École de santé publique Institut de recherche en santé publique de l'Université de Montréal (IRSPUM)

Montréal, QC

MAUDE LALIBERTÉ, PT, MSC

Programmes de bioéthique, Département de médecine sociale et préventive, École de santé publique Institut de recherche en santé publique de l'Université de Montréal (IRSPUM) Centre for Interdisciplinary Research in Rebabilitation of Greater Montreal (CRIR)

Montréal, QC

\begin{abstract}
When decision-makers are engaged in a polarized discourse and leaving aside evidencebased recommendations, is there a role for researchers in the dissemination of this scientific evidence to the general public as a means to counterbalance the debate? In response to the controversial Bill 10 in Quebec, we developed and posted a knowledge transfer video on YouTube to help stimulate critical public debate. This article explains our approach and methodology, and the impact of the video, which, in the space of two weeks, had more than 9,500 views, demonstrating the pertinence of such initiatives. We conclude with recommendations for other research groups to engage in public debates.
\end{abstract}




\section{Résumé}

En situation de débat polarisé dans lequel les décideurs laissent de côté les recommandations fondées sur les données probantes, les chercheurs peuvent-ils jouer un rôle dans la diffusion de données de recherche au grand public, dans le but de rééquilibrer le discours? En réponse au controversé projet de loi 10, au Québec, nous avons réalisé et affiché sur YouTube une vidéo de transfert de connaissances afin de stimuler un débat critique dans le grand public. Cette vidéo a été visionnée plus de 9500 fois en l'espace de deux semaines, ce qui démontre la pertinence d'initiatives de ce genre. Cet article explique notre démarche et notre méthodologie, ainsi que l'impact de la vidéo. En conclusion, nous formulons des recommandations pour d'autres groupes de recherche qui veulent participer aux débats publics.

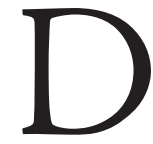

ISSEMINATION OF AND DISCUSSION ABOUT RESEARCH RESULTS ARE INCREASINGLY recognized as a necessary part of research (Barwick et al. 2014; Mitton et al. 2007), to the point that knowledge transfer (KT) is even viewed as an ethical duty and is now expected by funding agencies. The Canadian Institutes of Health Research (CIHR), for example, views KT as a measure of accountability for public investment in research (CIHR 2014). KT is especially important for population health researchers, whose research has a direct impact on the lives of individuals and communities (Estabrooks et al. 2008). However, it is not easy to transfer knowledge to the general public, especially when the subject is political, such as in the case of health system reorganization. KT becomes even more challenging when decision-makers seem to ignore evidence-based recommendations to advance ideologically driven agendas. A good example is Quebec's recently adopted and highly contentious Bill 10, modifying the organization and governance of health and social services (Minister of Health and Social Services 2015). When professional and academic experts are ignored by policy makers, it is imperative to explore innovative means of stimulating evidence-based public debate. In this context, we developed and released a video explaining the current state of knowledge about the likely consequences of the proposed reorganization and centralization of healthcare administration in Quebec. Our goal was to encourage citizens to think critically about Bill 10 and its impact on the healthcare system, and more specifically on service provision (Collectif d'étudiant(e)s en santé publique 2015).

To provide lessons for future video-based KT initiatives, we describe the process used to identify the relevant data to be presented, the communication strategies employed to make our video-based message effective, and the means selected to reach the population. Despite the limitations of a video formatted to be viral (about three minutes), the strategy we adopted proved to be an effective KT tool for generating positive public resonance. 


\section{Context}

Bill 10 was presented on September 25, 2014, at the Quebec National Assembly. This bill consists in the merger of 182 mid-level organizations (Centres de santé et services sociaux, CSSS) into 33 larger structures (Centres intégrés de santé et services sociaux, CISSS). It also includes the loss of 1,200 administrative positions, and greater power for the Health Minister (Minister of Health and Social Services 2015). The Bill was met with significant opposition from political parties, advocacy groups, unions, professional associations and academics. However, polls had shown that the population was divided on the subject (Léger 2014).

\section{Motivation and KT Approach}

On January 26, 2015, four leading healthcare policy and management researchers - Damien Contandriopoulos, Paul Lamarche, Réjean Hébert and François Béland - from the School of Public Health of the Université de Montréal (ESPUM), convened to discuss the impact of Bill 10, in a seminar organized by the Public Health Institute (IRSPUM) and the Department of Health Administration (DASUM). These scholars presented the relevant scientific data and healthcare management theory to a large group of researchers and graduate students. The full seminar was video-recorded but, lasting 95 minutes, it was far too lengthy to be made publicly accessible (IRSPUM 2015). The consensus among this group of specialists was clear: while the provisions presented in Bill 10 are unlikely to yield the expected savings and highly likely to be detrimental to patient care, the political context left no realistic options for stopping the reform. As a group of graduate students from ESPUM, we left the seminar feeling much more informed but also disempowered. We felt that (1) the information we had just received should not remain within the walls of the university, and that (2) the general public was capable of understanding, as well as entitled to be informed about, the implications of the upcoming reform. The Collectif d'étudiant(e)s en santé publique (hereafter, the Collective) was born.

To delineate our KT initiative, we adopted the CIHR (2014) definition of KT as "a dynamic and iterative process that includes synthesis, dissemination, exchange and ethically-sound application of knowledge to improve the health of Canadians, provide more effective health services and products and strengthen the health care system". Our initiative was action-oriented and aimed at stimulating critical thinking on the part of the general public; therefore, the use of social media was crucial as a means to create forums for exchange and discussion that are accessible.

When we initiated the project in late January, Bill 10 was still being studied in parliamentary committees, so we expected that we would have time to engage in the ongoing debate. A few days later, rumours started to spread that the government would invoke closure to end parliamentary debate. It became clear that we would not have time to release the video before the Bill's adoption. We could only hope to release it shortly after the Bill passed so that the topic may remain timely. We switched from a general awareness-raising purpose to an action-prompting goal, which in the end allowed us to include more information in our planned three-minute time frame. 


\section{Design of the Video and Communication Strategy}

Given that we are not experts in healthcare management, we relied primarily on the expert evidence presented at the January 26 seminar and related scientific literature in developing the content of the video. Of course, we reviewed the primary literature behind each information that we planned to include. To build the script for our video, we decided to adopt a six-step process, from the synthesis of relevant information to the mise en scène in a dialogue (Table 1a).

TABLE 1. Lessons learned during the writing of the script (a) and the dissemination of the video (b)

\begin{tabular}{|c|c|}
\hline \multicolumn{2}{|l|}{ a) Writing of the script } \\
\hline Writing process & Key lessons learned \\
\hline $\begin{array}{l}\text { Three authors established the main messages pertinent to } \\
\text { the general public }\end{array}$ & $\begin{array}{l}\text { The use of free brainstorming and iterative discussions on the purpose of the } \\
\text { message made it possible to identify the essential points for the general public }\end{array}$ \\
\hline $\begin{array}{l}\text { Three authors extracted the key data from the IRSPUM } \\
\text { seminar and relevant scholarly resources into a list of one- } \\
\text { line statements to be presented in the video }\end{array}$ & $\begin{array}{l}\text { The challenge of translating scholarly information into lay people's language } \\
\text { resides in preserving the meaning of the information, without sounding } \\
\text { alarmist, demagogic or ideological }\end{array}$ \\
\hline $\begin{array}{l}\text { One author transformed the two lists (message and key } \\
\text { data) into a dialogue }\end{array}$ & $\begin{array}{l}\text { It was difficult to establish a coherent story with each one-line statement } \\
\text { being linked with the previous and subsequent statements; staging the data } \\
\text { as a dialogue made for a more coherent and punchier narrative }\end{array}$ \\
\hline The authors refined the script iteratively & $\begin{array}{l}\text { Comments from students with various expertise and from collaborators } \\
\text { from the lay public allowed further specification and simplification of the } \\
\text { information presented }\end{array}$ \\
\hline $\begin{array}{l}\text { Two authors developed the visual concept with the } \\
\text { videographer }\end{array}$ & $\begin{array}{l}\text { Owing to time constraints, the use of visual effects, such as numbers, charts } \\
\text { or images, had to be ruled out; therefore, we needed a catchy, dynamic and } \\
\text { aesthetic visual concept in order to retain viewers' attention }\end{array}$ \\
\hline $\begin{array}{l}\text { The script was reviewed by the members of the Collective } \\
\text { (see Acknowledgements); minor modifications were made } \\
\text { to the tone, word selection and emphasis on certain } \\
\text { elements }\end{array}$ & $\begin{array}{l}\text { Ensuring each student's approval of the whole text was a good way to } \\
\text { ensure their buy-in to the project, but also to make sure that they were } \\
\text { comfortable saying their lines during the video shoot }\end{array}$ \\
\hline \multicolumn{2}{|l|}{ b) Dissemination of the video } \\
\hline Procedure for disseminating the video & Key lessons learned \\
\hline Synthesis of the message into a press release & $\begin{array}{l}\text { The assistance of communications specialists was highly valuable in formatting } \\
\text { an efficient press release and developing an effective release strategy }\end{array}$ \\
\hline $\begin{array}{l}\text { An e-mail account and YouTube channel were created for } \\
\text { the Collective. A Twitter account and a Facebook page } \\
\text { were also created to disseminate the YouTube link }\end{array}$ & $\begin{array}{l}\text { These channels allowed easy reach to the public and dissemination of } \\
\text { the video to the relevant interest groups and individuals, which facilitated } \\
\text { discussion of the message and content }\end{array}$ \\
\hline $\begin{array}{l}\text { Identification of the main point of contact in the traditional } \\
\text { media (newspaper, TV and radio) }\end{array}$ & $\begin{array}{l}\text { Support from communication specialists helped in identifying key contacts, } \\
\text { something that we had no experience with }\end{array}$ \\
\hline Launch of the video & $\begin{array}{l}\text { Time was of the essence, as by the time we were able to release the } \\
\text { video, Bill I } 0 \text { was already "old news" for traditional media; many journalists } \\
\text { re-tweeted our messages and video and congratulated us, but our initiative } \\
\text { did not elicit traditional media interest }\end{array}$ \\
\hline $\begin{array}{l}\text { During the social media dissemination, political parties and } \\
\text { advocacy organizations were excluded from the targets }\end{array}$ & $\begin{array}{l}\text { This allowed us to maintain our independence and remain politically } \\
\text { non-partisan }\end{array}$ \\
\hline
\end{tabular}


With the videographer, we developed the visual effect of superimposing each speaker in the background and half of his/her face in the forefront. Having a student staring at the camera with a flat affect while their disincarnated face is talking gave the impression of being in the thoughts of each individual, who could not speak aloud, and thus reminded the viewer of the charged political context in which the Bill was adopted.

The concept was chosen to help bridge the gap between scientific research and the general public. So that evidence would be anchored in people's lives, we decided not to play with the epistemic authority of the expertise of academics (and biases that may come with this). Rather than associating the evidence to academics, we chose to create a dialogue between students of the Collective about the impact of this latest healthcare reform in Quebec and the new law's expected consequences for the population. We contemplated the idea of displaying an academic reference for each statement, but since one of our first objectives was inclusivity, considering the low level of health literacy in Canada (Rootman and GordonEl-Bihbety 2008), we chose to preserve the simplicity of our aesthetic and message. Adding references would have also made video editing longer, and thus would have exacerbated the negative impact of the delay we experienced between the adoption of the law and the video release. However, upon request of some users on YouTube, we posted a short annotated bibliography along with the video. In order to keep it to a "viral" format (Jiang et al. 2014), we wanted the video to be as close to three minutes as possible (the video is $3 \mathrm{~m} 20$ s, excluding credits); this took five hours of shooting and about 20 hours of video editing. In the dissemination process (Table $1 \mathrm{~b}$ ) and in our press release (also posted on our YouTube channel), we included the IRSPUM's link to a webcast of the seminar.

\section{Outcomes and Exchanges}

The fact that two weeks after the February 16 launch the video had already hit 9,587 views on YouTube, is a demonstration that a small-scale KT project can have an important public uptake if it is well planned. This number is all the more impressive when one considers some significant barriers that could have mitigated the video's uptake, i.e., the political nature of the subject, the language (the video is only in French and was not translated nor subtitled in English) and the topic's specific relevance to Quebec. A YouTube search for videos on the same topic allows to locate videos posted by health professional unions such as Fédération interprofessionnelle de la santé du Québec (FIQ) and Fédération de la santé et des services sociaux affiliée à la Confédération des syndicats nationaux (FSSS-CSN). Our video ranks second in views $(11,145$ after 11 months), next to a press conference of the FIQ president Régine Laurent (15,453 views). It has more views than a series of videos posted by FSSS-CSN, their most popular videos having been viewed 7,936, 7,308 and 6,878 times. Of note, in addition to representing hundreds of thousands of people, both FIQ's and FSSS-CSN's videos are showing political figures well-known to the general public, while the Collective had no recognized notoriety.

Using YouTube's statistical tools, we obtained more details about the viewers (Figure 1) and viewing patterns. Viewing peaked within the first 48 hours after the video's 
release (Figure 1a); demographic data (Figure 1b) is consistent with that expected for a French-speaking Quebec-focused initiative (Canada represents 96\% of the viewing, followed by France at $1 \%$ and the US at 1\%); and the gender of viewers is fairly equal. More unexpected is the age stratification: most views (40\%) are from the $25-34$ age range, which could be explained by the fact that the initiative has been disseminated through social media. Mobile device (phone and tablet) viewing is fairly equal to computer viewing (Figure 1c). On average, viewers watched the video for $2 \mathrm{~m} 37 \mathrm{~s}$, which may indicate that the provided number of views represents actual viewers.

In addition to the YouTube views and presence on social media (Twitter: 340 tweets, 131 re-tweets, $94.1 \mathrm{k}$ re-tweet reach, 78 mentions, $11.3 \mathrm{k}$ mention reach, 224 favourited; Facebook page: 208 likes for the Collective page and 1.8k video reach/83 video share, in two weeks), the video was presented during the Université de Montréal's Public Health Students Association's Symposium on February 18, which lead to applause from on-stage guest speakers and praise from various students, several of whom asked how they could join the Collective. Various organizations, better established than the Collective, also approached us to discuss the video aftermath, and we received invitations to present our initiative in sociopolitical events and an article was published in a physiotherapy magazine (Anonymous 2015).

The only negative comments that we received pertained to the fact that we did not use references to back up the statements in the video. For example, on the YouTube channel, three people posted comments questioning our legitimacy, and the validity and reliability of our information. We anticipated this situation when we chose not to include references, and were able to mitigate the negative impact of this decision by answering the comments on YouTube by providing more detailed and referenced information.

\section{The Importance of Acquiring KT Abilities Early in an Academic Career}

It is important to remember that it takes a substantial amount of time to carry out such KT projects. Producing a three-minute video took two weeks of full-time work by three people, one full day of shooting involving 10 students and punctual help from several others. Due to the short window of opportunity, we had to put aside our concurrent academic projects. Relatively few people outside of academia (and even within academia) have the liberty to dedicate their full attention to this kind of project, for weeks (Bélisle Pipon et al. 2016). The three authors of the video (and this paper) are doctoral students, and thus benefit from a flexibility that others (such as researchers or clinicians) may not have. Considering that doctoral students generate a good deal of scientific research - for instance, 33\% of total research papers published in 2007 by Quebec researchers were written with doctoral students (Larivière 2010: 164) - it is logical to think that these knowledge producers should be more involved in KT. While Graham (2005) found that researchers "lack the skills, experience and confidence" in doing KT, an initiative like ours may help graduate students build their confidence through experience and skill-building to interact efficiently with a broad and diverse audience. 
FIGURE 1. Viewing statistics from February I 5 to March 3, 20I5: a) Views per day; b) Demographic information; c) Devices used for viewing
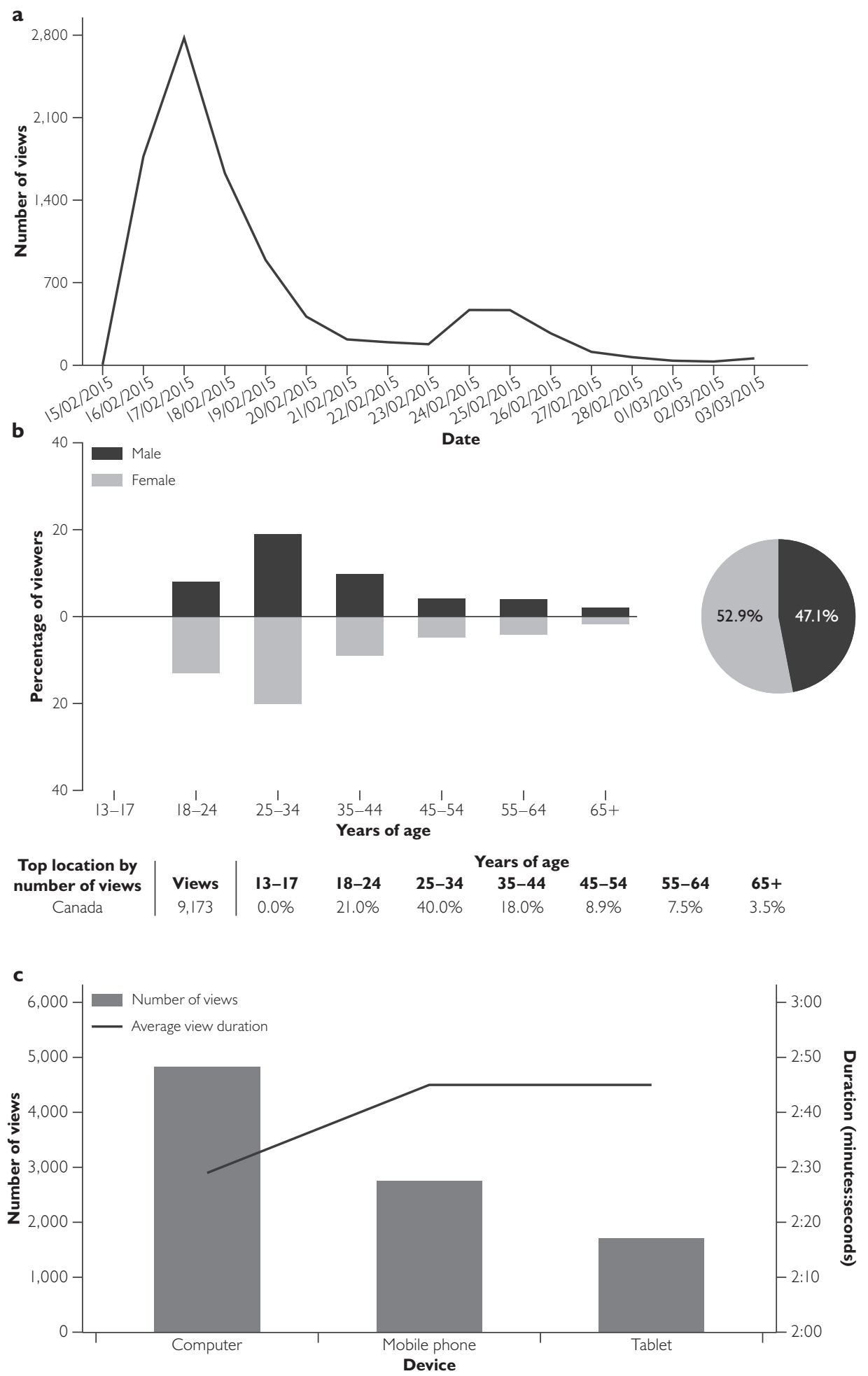
Moreover, it is even more important as $\mathrm{KT}$ is increasingly seen as a new expectation by funding agencies, and researchers themselves, as a token of accountability for knowledge producers (CIHR 2014). For instance, leading public health researchers are advocating for increased KT involvement: "A willingness and capacity to engage with mass media was seen as an essential attribute of influential public health researchers" (Chapman et al. 2014: 271). It can be argued that there is a fine line between "politicizing" science and advocating for evidence-based decision-making (Weigold 2001); however, when the goal is to raise awareness in the general public about well-accepted evidences, entering in the media sphere should not be seen as undermining researchers' integrity. Unfortunately, negative views remain against those engaging into debates in the public arena (Müllerleile 2014). Nevertheless, it should be recognized that it is the researchers' duty and that mass media are "an invaluable mechanism [for] influencing policy change" (Chapman et al. 2014: 271).

\section{Concluding Note}

Creating a video aimed at transferring knowledge about public policy to the general public is challenging, especially when the political context makes for a tight window of opportunity. However, the experience was a success considering the number of views and positive comments received (online and in person). The framework used to design our KT project can, we hope, provide a useful map for scholars to plan similar KT initiatives that help to bridge the gap between research and the general public.

\section{Acknowledgements}

We would like to thank, first of all, the other members of the Collectif d'étudiant(e)s en santé publique who were involved in creating the video that is the subject of this paper: Aliya Affdal, Dimitri Dubé-Marquis, Marjolaine Frenette, Patrick Anges Gogognon, Hazar Haidar, Geneviève McCready and Elise Smith. We are grateful to François Pènzes and Mathieu Vinuesa for their technical support in producing the video. We also thank Dominique Lemoine and Caroline Boily for their advice in the dissemination of the video. We would also like to acknowledge and thank Bryn Williams-Jones for his support throughout this initiative and his comments on this paper. This initiative received financial support from the Axe éthique et intégrité en santé des populations. Bélisle Pipon is supported by a scholarship from the Fonds de recherche du Québec - Santé (FRQ-S) \& Unité SUPPORT-SRAP du Québec. Lemoine is supported by scholarships from the Institut de recherche en santé publique de l'Université de Montréal (IRSPUM), the Centre de recherche en éthique (CRÉ), the PEGASUS project and the Fonds de recherche du Québec - Santé (FRQ-S). Laliberté is supported by a scholarship from the Fonds de recherche du Québec - Santé (FRQS). The views expressed in the video and in this paper are those of the authors, and do not reflect the position of any of the funders.

Correspondence may be directed to: Jean-Christophe Bélisle Pipon; e-mail: jean-christophe.belisle.pipon@umontreal.ca; tel.: +1 514-343-6111, ext. 49373. 


\section{References}

Anonymous. 2015. Des étudiants en santé publique contre la loi 10. Parallèle. Retrieved March 1, 2015. <http:// parallelephysio.ca/actupro/au-quebec/un-video-des-etudiants-en-sante-publique-contre-la-loi-10/>.

Barwick, M., D. Phipps, G. Myers, M. Johnny and R. Coriandoli. 2014. "Knowledge Translation and Strategic Communications: Unpacking Differences and Similarities for Scholarly and Research Communications." Scholarly and Research Communication 5(3). Retrieved January 9, 2016. <http://src-online.ca/index.php/src/ article/view/175>.

Bélisle Pipon, J.-C., M.-E. Lemoine, M. Laliberté and B. Williams-Jones. 2016. "Between Policy and Politics: When Bioethics Ventures into Public Debate." Narrative Inquiry in Bioethics 6(1).

Canadian Institute for Health Research (CIHR). 2014. Knowledge Translation E Commercialization. Retrieved February 22, 2016. <http://www.cihr-irsc.gc.ca/e/29529.html>.

Chapman, S., A. Haynes, G. Derrick, H. Sturk, W.D. Hall and A.S. George. 2014. "Reaching "An Audience that you would Never Dream of Speaking to": Influential Public Health Researchers' Views on the Role of News Media in Influencing Policy and Public Understanding." Journal of Health Communication 19(2): 260-73. doi:10.1080/10810730.2013.811327.

Collectif d'étudiant(e)s en santé publique. 2015. Les faits sur la loi 10. Montréal. Retrieved January 9, 2016. $<$ www.youtube.com/watch?v=khbsgbqtuvQ>.

Estabrooks, C.A., P. Norton, J.M. Birdsell, M.S. Newton, A.J. Adewale and R. Thornley. 2008. "Knowledge Translation and Research Careers: Mode I and Mode II Activity among Health Researchers." Research Policy 37(6): 1066-78.

Graham, I. 2005. How Are Canadian Health Researchers Promoting the Uptake of their Findings. Presented at the KT ICEBeRG Symposium - Ottawa Health Research Institute, The Ottawa Hospital (Civic Campus), Ottawa, Canada. Retrieved January 9, 2016. <http://www.iceberg-grebeci.ohri.ca/research/ICEBeRG_symposium_Graham.pdf $>$.

IRSPUM. 2015. Les implications du projet de loi no. 10. Montréal. Retrieved January 9, 2016. <www.irspum. umontreal.ca/DOCUMENTATIONETRESSOURCES/M\%C3\%89DIATH\%C3\%88QUE/tabid/79/language/fr-CA/Default.aspx?Id=4084>.

Jiang, L., Y. Miao, Y. Yang, Z. Lan and A.G. Hauptmann. 2014. "Viral Video Style: A Closer Look at Viral Videos on YouTube." In Proceedings of International Conference on Multimedia Retrieval (p. 193). ACM. Retrieved January 9, 2016. <http://dl.acm.org/citation.cfm?id=2578754>.

Larivière, V. 2010. A Bibliometric Analysis of Quebec's PhD Students' Contribution to the Advancement of Knowledge. McGill University. Retrieved January 9, 2016. <www.ost.uqam.ca/Portals/0/docs/Monographies/ Thesis_Lariviere_Final.pdf $>$.

Léger. 2014. Perceptions du projet de loi 10 sur la réforme de la santé et des services sociaux. Montréal, Québec. Retrieved January 9, 2016. <http://www.fsss.qc.ca/download/vpp/Rapport-FSSS_CSN-PL10.pdf>.

Minister of Health and Social Services. 2015. Bill № 10: An Act to modify the Organization and Governance of the Health and Social Services Network, in Particular by Abolishing the Regional Agencies - National Assembly of Québec, § 41th Legislature. Retrieved January 9, 2016. <www.assnat.qc.ca/en/travaux-parlementaires/projets-loi/ projet-loi-10-41-1.html>.

Mitton, C., C.E. Adair, E. Mckenzie, S.B. Patten and B.W. Perry. 2007. "Knowledge Transfer and Exchange: Review and Synthesis of the Literature." Milbank Quarterly 85(4): 729-68. doi:10.1111/j.1468-0009.2007.00506.x.

Müllerleile, A. 2014. "European Studies and Public Engagement: A Conceptual Toolbox." Journal of Contemporary European Research 10(4): 505-17. Retrieved January 9, 2016. <www.jcer.myzen.co.uk/index.php/ jcer/article/view/647>.

Rootman, I. and D. Gordon-El-Bihbety. 2008. Vision for a Health Literate Canada: Report of the Expert Panel on Health Literacy. Canadian Public Health Association. Retrieved January 9, 2016. <www.cpha.ca/uploads/ portals/h-1/report_e.pdf>

Weigold, M. 2001. “Communicating Science." Science Communication 23(2): 164-93. 